\title{
Хроническая фистула
}

\section{для изучения микробиома слепой кишки кролика}

\author{
Г. Ю. Косовский ${ }^{1 凶}$, Е. С. Колесник ${ }^{1}$, Д. В. Попов ${ }^{1}$ \\ ${ }^{1}$ Научно-исследовательский институт пушного звероводства и кролиководства имени \\ В. А. Афанасьева, Родники, Россия \\ ఐE-mail: niipzk@mail.ru
}

Аннотация. Цель настоящей работы - апробация устройства для изучения микробиома желудочно-кишечного тракта млекопитающих. Исследование количественного и качественного состава микробиоты органов пищеварения - одно из перспективных направлений в метагеномике. Полученные знания об организации генома микробиоценоза, определение видового состава и изучение метаболических взаимосвязей между его представителями не только позволяют расширить понимание его роли в процессе эволюции, видо- и породообразования, но и дают научно аргументированную основу для целенаправленного изменения микробиома с целью формирования фенотипа (оптимизация биоконверсии корма, повышение общей резистентности и т. д.). Научная новизна. Впервые через хроническую фистулу выделены, культивированы и описаны основные характеристики целлюлозолитических бактерий, выделенных из химуса слепой кишки кролика. Методы. Для проведения исследований, направленных на изучение микробиома млекопитающих и его коррекции, возникает необходимость в разработке методов получения образцов микробиома от экспериментальных животных. Для получения доступа к химусу слепой кишки 7 кроликам на срок до 3 месяцев были установлены разработанные в ФГБНУ НИИПЗК хронические фистулы. После установки фистул у животных не отмечалось никаких негативных проявлений, не было обнаружено изменений в аппетите, на 9-е сутки определено полное заживление раны кожи. В ходе диагностических лапаротомий, проведенных через 3 месяца после установки фистул, ни у одного исследуемого животного не выявлено патологических процессов. Результаты. Изучены характеристики целлюлозолитических бактерий слепой кишки кролика Butirivibrio fibrisolvens и Ruminococcus flavefaciens. Приведены данные по их ферментному воздействию на составляющие рационов, продуктам ферментации, сбраживанию и образованию органических веществ и химических соединений.

Ключевые слова: кролик, микробиом, целлюлосомы, фистула, химус, Butirivibrio fibrisolvens, Ruminococcus flavefaciens.

Для цитирования: Косовский Г. Ю., Колесник Е. С., Попов Д. В. Хроническая фистула для изучения микробиома слепой кишки кролика // Аграрный вестник Урала. 2021. № 10 (213). C. 40-47. DOI: 10.32417/19974868-2021-213-10-40-47.

Дата поступления статьи: 06.07.2021, дата рецензирования: 20.07.2021, дата принятия: 02.09.2021.

\section{Постановка проблемы (Introduction)}

Метагеномика является перспективным направлением, имеет огромную научную значимость, при этом знания, полученные при изучении этой области, позволяют повысить эффективность различных отраслей животноводства [1]. Известно, что симбионты микробиома оказывают влияние практически на все физиологические процессы организма: от формирования иммунитета и резистентности [2] до процессов пищеварения и воспроизводства [3]. Накопленные знания показывают, что изменения микробиома животных в ходе доместикационного процесса, связанные с общей нишей, формируемой вместе с человеком, влияют не только на поведенческие, но и на фенотипические признаки [4]. Изучение микробиома желудочно-кишечного тракта млекопитающих в настоящее время является актуальной темой, так как в последние годы активно развивается теория о 40 его роли в процессах эволюции и доместикации [4]. Формирование общей ниши оказывает влияние на адаптацию видо- и породообразования млекопитающих и микробиома. Микробиом кишечника является одним из факторов, формирующих изменения рациона, фенотипическую изменчивость и адаптивный потенциал млекопитающих [4]. Последние данные свидетельствуют о том, что бактериальный дисбиоз может способствовать психическим расстройствам, индуцированным цитокин-опосредованными реакциями, наблюдаемыми у пациентов с кишечными заболеваниями [5], [6]. В настоящее время исследования микробиома одомашненных видов животных имеют большое значение, так как продуктивность и устойчивость сельскохозяйственных ценных видов и пород животных могут быть улучшены целенаправленным изменением качественного и количественного состава микробиома. Однако организация этого процесса 
является сложной задачей из-за недостаточно изученной роли симбионтов микробиома различных видов животных и взаимодействия «микробиом - хозяин».

В кролиководстве одним из актуальных направлений является изучение микробиоценоза слепой кишки кролика [7]. Значимость этого направления определяется, прежде всего, тем, что целлюлоза (клетчатка), являясь основным структурным компонентом оболочек растительных клеток, не метаболизируется ферментной системой кролика [8], а этот процесс обеспечивается ферментами бактерий, локализирующимися в слепой кишке [9]. Переваримость сырой клетчатки у кроликов составляет приблизительно $20 \%$ в грубых кормах и до $45 \%$ в травяном корме и зерне [10]. Поскольку основная роль микробиома слепой кишки заключается в ферментации клетчатки, наибольший интерес представляет определение целлюлозолитической активности бактерий слепой кишки, при этом при проведении исследований с целью изучения организации геномов микробиома слепой кишки кролика необходимой задачей остается выявление видового состава и метаболических взаимосвязей между его представителями.

Целлюлазы (целлюлозолитические ферменты) ферменты класса гидролаз, катализирующие гидролиз 1,4-гликозидных связей в молекуле целлюлозы с образованием набора олигосахаридов различной степени полимеризации вплоть до мономера - глюкозы [11]. Целлюлосома является одной из наиболее эффективных систем для расщепления целлюлозы. Этот мультиферментный внеклеточный комплекс включает в себя различные гидролитические ферменты [12]. Активность целлюлосом была тщательно изучена у многих целлюлозолитических бактерий [12]. Среди анаэробных бактерий один из известных продуцентов целлюлаз Bacteroides cellulosolvens первоначально был выделен из осадка сточных вод [13] и имеет способность связывать и разлагать кристаллическую целлюлозу [14]. B. cellulosolvens содержит самые большие некаталитические целлюлосомные субъединицы, известные до настоящего времени, что указывает на наличие особенно сложной целлюлосомной системы [15]. Из неспорообразующих анаэробных микроорганизмов в слепой кишке кролика доминируют грамположительные бифидобактерии [16]. Симбиотическая роль в отношениях бифидобактерий с макроорганизмом очень важна и заключается как в участии в процессе пищеварения, так и в формировании резистентности и иммунных свойств организма. Благодаря способности к адгезии обеспечивается поверхностное прикрепление бифидобактерий к слизистой кишечника, тем самым обеспечивается их участие в пристеночном пищеварении, ферментации субстратов и конкуренции за пищевую нишу с другими представителями микробиоты кишечника. В результате колонизации бифидобактериями слизистой кишечника на его поверхности образуются биопленки, которые препятствуют размножению патогенных и условно патогенных бактерий, тем самым обеспечивая формирование локальной резистентности [17]. Способность к образованию ацетата, лактата, летучих жирных кислот, лизоцимоподобных и других веществ с антибактериальной активностью определяет их антагонистическая активность. При использовании аммиака в просвете кишечника для синтеза собственных структурных белков бифидобактерии подавляют токсинообразование и разрушают токсины патогенных бактерий и кормов, тем самым существенно снижая токсическую нагрузку на печень [18].

Для проведения долговременных исследований процессов физиологии пищеварения млекопитающих, получения доступа к химусу, желудочному соку, содержимому кишечника применяют методы, основанные на канюлировании органов пищеварительной системы на различных уровнях. Для этого млекопитающим в зависимости от целей и задач исследования в органы пищеварительной системы хирургическим способом устанавливают специальные устройства фистулы (канюли), обеспечивающие возможность получать содержимое органа (химус, желудочный сок) пищеварительной системы либо вводить во внутреннюю полость органа терапевтические препараты, микроорганизмы, компоненты корма. Сегодня разработано и проведено множество исследований, направленных на изучение процессов пищеварения млекопитающих, в том числе и изучение активности целлюлаз в пищеварительном тракте кроликов in vivo $^{1}$, которые имеют как преимущества, так и недостатки ${ }^{2}$.

Целью исследования является разработка хронической фистулы и изучение ферментативной активности целлюлозолитических бактерий слепой кишки Butirivibrio fibrisolvens и Ruminococcus flavefaciens на примере доместицированного вида сельскохозяйственных животных - Oryctolagus cuniculus war. domestica.

Методология и методы исследования (Methods)

Фистула. Разработанная фистула представляет собой пластиковую трубку с монолитно выполненными на ее дистальном конце крыльями, которые препятствуют выпадению фистулы из органа пищеварительной системы, при этом фистула фиксируется резиновыми валиками на слепой кишке и коже животного и имеет завинчиваемую пробку.

${ }^{1}$ Пат. 2470293 Российская Федерация, МПК G01N 33/00 (2006.01). Способ определения активности целлюлазы в пищеварительном тракте кроликов in vivo / Гаврикова Е. И., Лактионов К. С., Лактионова Т. К. и др.; заявитель и патентообладатель ФГБОУ ВПО Орел ГАУ. - № 2011146841/15; заявл. 17.11.2011; опубл. 20.12.2012, Бюл. № 35.

2 Пат. 198197 Российская Федерация, МПК G09B 23/28 (2006.01), A61B 17/22 (2006.01), A61B 17/50 (2006.01). Фистула для изучения физиологических процессов пищеварения у млекопитающих / Косовский Г. Ю., Попов Д. В.; заявитель и патентообладатель ФГБНУ НИИПЗК. - № 2020106301; заявл. 10.02.2020; опубл. 23.06.2020, Бюл. № 18. 


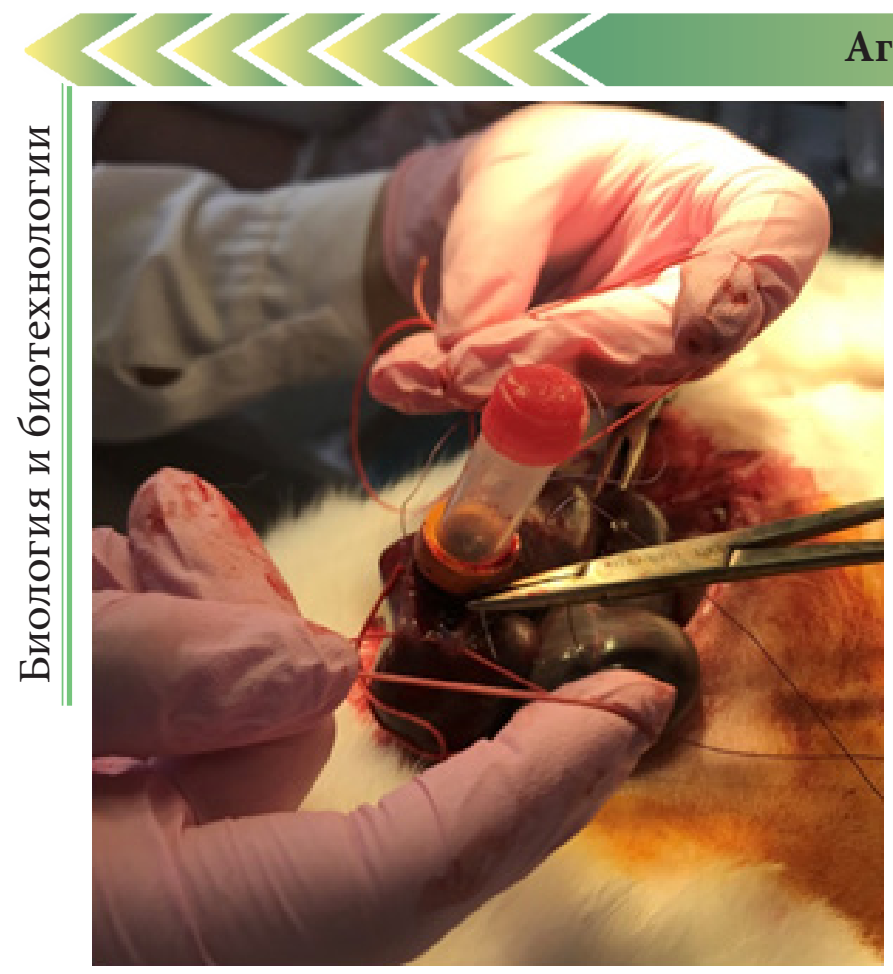

Рис. 1. Установка фистуль на слепую кишку кролика Fig. 1. Installation of a fistula on a rabbit's cecum

Хирургическая установка фистуль. Перед операцией кроликов выдерживали на голодной диете в течение 12 часов с неограниченным доступом к воде. Для премедикации применяли атропина сульфат $0,1 \%$ (0,5 мл), наркоз проводили препаратом «Пропофол» 20 \%. Препарат вводили внутривенно, дозировали индивидуально по рефлексам из расчета изначальной дозы 7,5-15 мг/кг.

Животное располагали на операционном столе лежа на спине. Операционное поле выбривали от шерсти, обрабатывали по Филончикову - Гроссиху и изолировали с помощью нетканой одноразовой салфетки и цапок. Хирургический доступ проводили согласно топографии слепой кишки. Все кровотечения из сосудов кожи, подкожной жировой клетчатки и брюшной стенки устраняли путем электрокоагуляции. После определения места установки фистулы на слепой кишке делали разрез и вставляли одно из крыльев фистулы в просвет раны и круговым движением по часовой стрелке вводили фистулу во внутреннюю полость слепой кишки. Затем для закрытия зияния раны накладывали кисетный шов полигликолидной нитью (ПГА) (рис. 1).

После чего к ушитому разрезу органа пищеварительной системы продвигали резиновый валик. Далее закрывали брюшную стенку, с этой целью применяли непрерывный шов с использованием шовного материала Vicryl Rapide 2/0. Для закрытия зияния раны кожи применяли внутрикожный шов с использованием в качестве шовного материала Vicryl Rapide 2/0. Далее обрабатывали рану средством, способствующим заживлению, алюминиум-спреем («Никовет» (Nicovet), Германия) и располагали еще один резиновый валик таким образом, чтобы обеспечить фиксацию фистулы и предупредить ее продвижение в брюшную полость грарный вестник Урала № 10 (213), 2021 г.

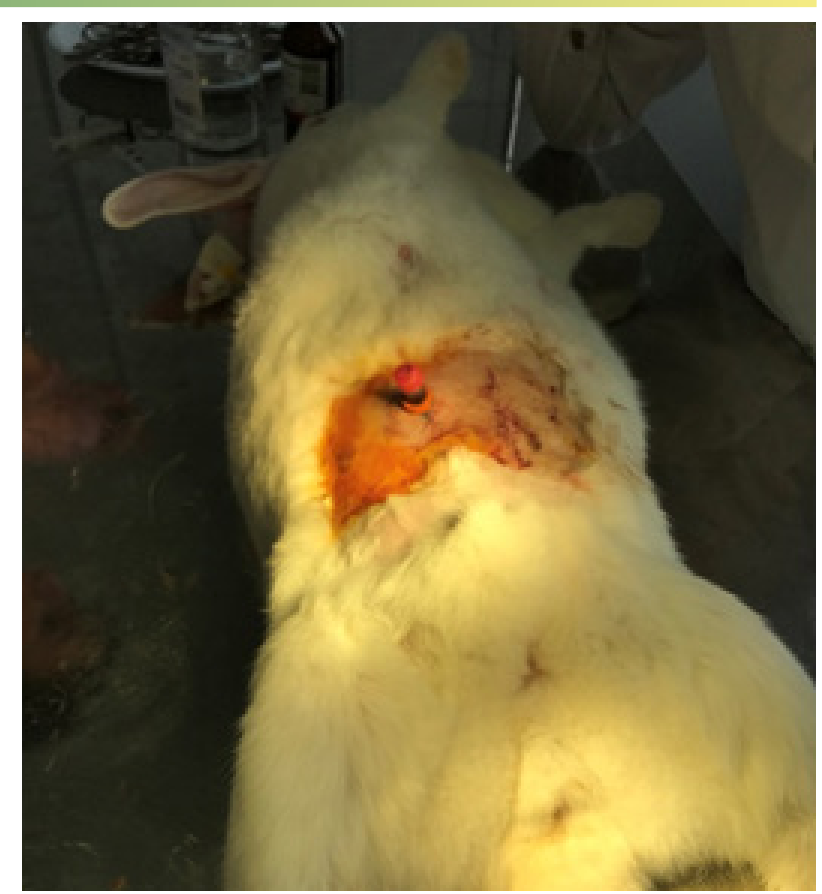

Рис. 2. Установленная фистула (вид со стороны кожи) Fig. 2. Installed fistula (skin view)

(рис. 2). Хронические фистулы в слепую кишку были установлены 7 кроликам на срок до 3 месяцев. После проведения исследования с целью определения успешности заживления ран была сделана диагностическая лапаротомия животных.

Выделение и изучение характеристик Butirivibrio fibrisolvens u Ruminococcus flavefaciens. С целью изучения биохимических характеристик целлюлозолитических бактерий Butirivibrio fibrisolvens и Ruminococcus flavefaciens получали химус из слепой кишки через установленную фистулу.

Для культивирования целлюлозолитических микроорганизмов химуса кролика использовали жидкую среду Гетчинсона и Хангейта. Выделение чистой культуры микроорганизмов проводили пересевом на плотную среду Гетчинсона. В качестве питательного субстрата использовали обеззоленную фильтровальную бумагу. Культивирование проводили с применением газогенерирующей системы GENbox CO2 для создания анаэробных условий в замкнутой воздушной среде, при температуре $37^{\circ} \mathrm{C}$. Солеустойчивость определяли на питательных средах с массовой долей хлористого натрия более 7,0 \% при температуре $37 \pm$ $1{ }^{\circ} \mathrm{C}$ в течение 48-72 ч.

Общее количество солеустойчивых микроорганизмов (КОЕ/г) вычисляли по формуле:

$$
X=n \cdot 10^{m} \cdot a,
$$

где $n$ - количество колоний, подсчитанных на чашке Петри;

$m$ - число десятикратных разведений;

$a$ - коэффициент пересчета, учитывающий объем посевного материала, вносимого в чашку Петри.

При посеве $0,1 \mathrm{~cm}^{3}$ коэффициент пересчета равняется 10; при посеве $0,2 \mathrm{~cm}^{3}-5$; при посеве $0,5 \mathrm{~cm}^{3}-2$. 


\section{Agrarian Bulletin of the Urals No. 10 (213), 2021}

Определение индола проводили по способу Мореля [19]. Наличие сероводорода определяли с помощью полоски фильтровальной бумаги, пропитанной раствором ацетата свинца и аммиака, помещенной между стенкой и пробкой засеянной пробирки. Каталазную активность устанавливали с использованием 3-процентного раствора перекиси водорода. Редукцию нитратов определяли на нитратном бульоне.

Морфологию, размеры клеток, колонии и подвижность бактерий оценивали визуально в микроскопе под иммерсией. Капсулообразование у бактерий определяли методом Бурри - Гинса [20]. Наличие спор у бактерии определяли методом Ожешко [20]. Окраску проводили по Граму. Подсчет численности микроорганизмов производили методом Брида. Кроме дифференциальной окраски по Граму, для подсчета численности йодофильных бактерий применяли окраску раствором Люголя, для обнаружения спор метиленовой синью по Леффлеру [21].

Таблица 1

Характеристики бактерий Butirivibrio fibrisolvens и Ruminococcus flavefaciens, выделенных из химуса слепой кишки кролика

\begin{tabular}{|c|c|c|}
\hline Характеристики & $\begin{array}{l}\text { Butirivibrio } \\
\text { fibrisolvens }\end{array}$ & $\begin{array}{l}\text { Ruminococcus } \\
\text { flavefaciens }\end{array}$ \\
\hline Тип дыхания & Анаэробное & Анаэробное \\
\hline Окраска по Граму & - & + \\
\hline \multicolumn{3}{|c|}{ Образуют } \\
\hline Каталаза & - & - \\
\hline Аммиак $\mathrm{NH}_{3}$ & - & - \\
\hline Индол $\mathrm{C}_{8} \mathrm{H}_{7} \mathrm{~N}$ & - & - \\
\hline Сероводород $\mathrm{H}_{2} \mathrm{~S}$ & 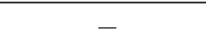 & 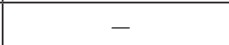 \\
\hline $\begin{array}{l}\text { Редуцирование } \\
\text { нитрата }\end{array}$ & - & - \\
\hline \multicolumn{3}{|c|}{ Ферментируют } \\
\hline Целлюлоза & + & + \\
\hline Целлобиоза & + & + \\
\hline Глюкоза & + & + \\
\hline Лактоза & + & - \\
\hline Сахароза & + & - \\
\hline Мальтоза & + & \\
\hline Крахмал & + & \\
\hline Салицин & + & \\
\hline Ксилан & + & + \\
\hline Пектин & + & \\
\hline \multicolumn{3}{|c|}{ Сбраживают } \\
\hline Трегалоза & - & \\
\hline Маннитол, & - & \\
\hline Глицерол & - & \\
\hline \multicolumn{3}{|c|}{ Продукты ферментации } \\
\hline Масляная кислота & + & \\
\hline $\begin{array}{l}\text { Муравьиная } \\
\text { кислота }\end{array}$ & + & + \\
\hline Молочная кислота & + & \\
\hline Водород & + & + \\
\hline Углекислый газ & + & + \\
\hline
\end{tabular}

\section{Результаты (Results)}

Известно, что при установке хронических фистул в органы пищеварения при процессе заживления нередко возникают осложнения: воспаление и сращение органа пищеварительной системы, в который установлена фистула (слепая кишка, желудок и т. д.), и между серозными слоями брюшины, что влечет за собой функциональные расстройства (нарушение перистальтики кишечника, мышечное сокращение желудка и т. д.). Кроме того, из органа пищеварительной системы, в который установлена фистула, в брюшную полость может попасть его содержимое, что приведет к возникновению септических процессов (перитонит) либо процессов самопереваривания (автолиз). Поэтому важно при разработке, подборе материалов и установке таких устройств предусмотреть ряд характеристик и свойств, таких как надежная фиксация фистулы во внутреннем просвете органа (слепая кишка, желудок и т. д.) и на наружной поверхности органа и кожи, гипоаллергенность и низкая адгезивность.

Table 1

Characteristics of the bacteria Butirivibrio fibrisolvens and Ruminococcus flavefaciens isolated from the chyme of rabbit cecum

\begin{tabular}{|c|c|c|}
\hline Features & $\begin{array}{l}\text { Butirivibrio } \\
\text { fibrisolvens }\end{array}$ & $\begin{array}{l}\text { Ruminococcus } \\
\text { flavefaciens }\end{array}$ \\
\hline Type of breathing & Anaerobic & Anaerobic \\
\hline Gram stain & - & + \\
\hline \multicolumn{3}{|c|}{ Forming } \\
\hline Catalase & - & - \\
\hline Ammonia $\mathrm{NH}_{3}$ & - & - \\
\hline Indole $\mathrm{C}_{8} \mathrm{H}_{7} \mathrm{~N}$ & - & - \\
\hline $\begin{array}{c}\text { Hydrogen sulfide } \\
H_{2} S\end{array}$ & - & - \\
\hline Reducing nitrate & - & - \\
\hline \multicolumn{3}{|c|}{ Fermenting } \\
\hline Cellulose & + & + \\
\hline Cellobiose & + & + \\
\hline Glucose & + & + \\
\hline Lactose & + & - \\
\hline Sucrose & + & - \\
\hline Maltose & + & \\
\hline Starch & + & \\
\hline Salicin & + & \\
\hline Xylan & + & + \\
\hline Pectin & + & \\
\hline \multicolumn{3}{|c|}{ Fermenting } \\
\hline Trehalose & - & \\
\hline Mannitol, & - & \\
\hline Glycerol & - & \\
\hline \multicolumn{3}{|c|}{ Fermentation products } \\
\hline Butyric acid & + & \\
\hline Formic acid & + & + \\
\hline Lactic acid & + & \\
\hline Hydrogen & + & + \\
\hline Carbon dioxide & + & + \\
\hline
\end{tabular}


После установки фистул опытные животные не проявляли аллергической реакции, на 9-е сутки отмечено полное заживление раны кожи. Изменений в аппетите обнаружено не было. В ходе диагностических лапаротомий, проведенных через 3 месяца после установки фистул, ни у одного исследуемого животного не выявлено патологических процессов, слизистая оболочка слепой кишки кролика была блестящей, бледно-розового цвета, что соответствует нормам, применяемые шовные материалы полностью были подвержены резорбции, образовавшаяся рубцовая ткань была бледно-розового цвета, полностью закрывшая зияние раны.

Во второй части проведенного исследования мы изучали биохимические характеристики целлюлозолитических бактерий слепой кишки кролика Butirivibrio fibrisolvens и Ruminococcus flavefaciens (таблица 1).

Установлено 32 млрд микроорганизмов в 1 г химуса. При культивировании на селективной среде с фильтровальной бумагой были выделены целлюлозолитические бактерии Butirivibrio fibrisolvens и Ruminococcus flavefaciens. Butirivibrio fibrisolvens анаэробные подвижные изогнутые палочковидные бактерии, расположенные одиночно и в виде небольших цепочек.

При проведении дальнейшего исследования на культуре Butirivibrio fibrisolvens были выявлены следующие биохимические характеристики: каталазу, аммиак, индол, сероводород не образуют, нитрат не редуцируют; ферментируют целлюлозу, целлобиозу, глюкозу, лактозу, сахарозу, мальтозу, крахмал, салицин, ксилан и пектин; не сбраживают трегалозу, маннитол, глицерол; продуктами ферментации являются масляная, муравьиная и молочная кислоты, водород и углекислый газ.

Изучение биохимических свойств Ruminococcus flavefaciens показало: каталазу, аммиак, индол, сероводород не образуют; нитрат не редуцируют; ферментируют целлюлозу, целлобиозу, глюкозу и ксилан; не ферментируют декстрин, лактозу, мальтозу, ксилозу, сахарозу; продуктами ферментации являются уксусная и муравьиная кислоты, сукцинат, ацетат, углекислый газ и водород.

Обсуждение и выводы (Discussion and Conclusion)

Оболочка $B$. Fibrisolvens содержит производные тейхоевой кислоты, характерные для грамположительных клеток. Есть данные, где указано, что в геноме присутствует большой набор генов, участвующих в целлюлозолитическом процессе, но отсутствуют ключевые гены, участвующие в биогидрировании углеводов [22]. Это, по-видимому, указывает на то, что B. Fibrisolvens играет важную роль в целлюлозолитических процессах в рубце, но не обладает автономной целлюлозолитической способностью. На жидкой среде вызывает небольшое помутнение и хлопьевидный осадок. На плотной - кремовые колонии звездчатой формы.
Ruminococcus flavefaciens - грамположительные неподвижные анаэробные бактерии кокковой формы, располагаются парами или короткими, или длинными цепочками. Спор не образуют. Бактерия является сильным целлюлозолитическим штаммом, который способен разрушать нерастворимую кристаллическую целлюлозу, присутствующую в тестовых субстратах, таких как фильтровальная бумага и депарафинированное хлопковое волокно [23]. На плотной питательной среде образуют мелкие (2-3 мм в диаметре) колонии в форме двояковыпуклой линзы, беловатой или слабо желтой окраски.

Бактериальные штаммы Butirivibrio fibrisolvens и Ruminococcus flavefaciens являются одними из самых значительных целлюлозолитических бактерий в кишечнике травоядных животных. Особенностью представленных бактерий является то, что они метаболизируют все тестовые субстраты целлюлозы, образуя конъюгированную линолевую кислоту (CLA), которая формируется в качестве промежуточного продукта во время биогидрирования линолевой (LA) и альфа-линоленовой кислот, которые имеют начальную стадию изомеризации с образованием конъюгированной цис9, транс-11-кислоты, которая затем подвергаются гидрированию своих цис-двойных связей, что приводит к транс-11-окатдекановой кислоте (транс-вакценовой кислоте, 11-эладиковой кислоте) с последующим гидрированием до стеариновой кислоты [24]. Подъем концентрации CLA в кишечнике животных приводит к повышению ее уровня в мясе, что положительно сказывается на функциональных свойствах мяса, а также может улучшить его качество, включая устойчивость к окислению, увеличивает время хранения сырого мяса и позволяет сохранять цвет мяса, что придает ему хороший товарный вид.

Полученные и представленные нами результаты подтверждаются имеющимися литературными данными [25]. Таким образом, можно сделать заключение, что проведенное исследование по изучению биохимических характеристик целлюлозолитических бактерий Butirivibrio fibrisolvens и Ruminococcus flavefaciens, выделенных из химуса слепой кишки кролика, который получали через установленную фистулу, показывает возможность применения и эффективность разработанного устройства для проведения физиологических исследований процессов пищеварения, изучения видового состава и свойств микробиоциноза слепой кишки кроликов в течение длительного времени. Получение новых знаний о составляющей микробиома слепой кишки кролика позволит в дальнейшем целенаправленно корректировать его видовой состав, что определит возможность управлять скоростью биоконверсии корма, создавая животных с направленными хозяйственно полезными признаками, необходимых для оптимизации в промышленном кролиководстве. 


\section{Библиографический список}

1. Cotozzolo E., Cremonesi P., Curone G., et al. Characterization of Bacterial Microbiota Composition along the Gastrointestinal Tract in Rabbits // Animals (Basel). 2020. No. 11 (1). Article number 31. DOI: 10.3390/ani11010031. 2. Arrazuria R., Pérez V., Molina E., Juste R. A., Khafipour E., Elguezabal N. Diet induced changes in the microbiota and cell composition of rabbit gut associated lymphoid tissue (GALT) // Scientific Reports. 2018. No. 8 (1). Article number 14103. DOI: 10.1038/s41598-018-32484-1.

3. Буштырева И. О., Буштырев В. А., Баринова В. В. [и др.] Микробиом женской репродуктивной системы: вопросов больше, чем ответов // Главный врач Юга России. 2018. № 3 (62). С. 49-52.

4. Kolodny O., Callahan B. J., Douglas A. E. The role of the microbiome in host evolution // Philosophical Transactions of the Royal Society. B. Biological Sciences. 2020. No. 375 (1808). Article number 20190588. DOI: 10.1098/ rstb.2019.0588.

5. Douglas-Escobar M., Elliott E., Neu J. Effect of intestinal microbial ecology on the developing brain // JAMA Pediatr. 2013. No. 167 (4). Pp. 374-379. DOI: 10.1001/jamapediatrics.2013.497.

6. Bercik P., Denou E., Collins J., et al. The intestinal microbiota affect central levels of brain-derived neurotropic factor and behavior in mice // Gastroenterology. 2011. No. 141 (2). Pp. 599-609. DOI: 10.1053/j.gastro.2011.04.052.

7. Velasco-Galilea M., Piles M., Viñas M., et al. Rabbit Microbiota Changes Throughout the Intestinal Tract // Frontiers in microbiology. 2018. No. 9. Article number 2144. DOI: 10.3389/fmicb.2018.02144.

8. Yang G., Zhao F., Tian H., Li J., Guo D. Effects of the dietary digestible fiber-to-starch ratio on pellet quality, growth and cecal microbiota of Angora rabbits // Asian-Australasian Journal of Animal Sciences. 2020. No. 33 (4). Pp. 623-633. DOI: 10.5713/ajas.19.0221.

9. Funosas G., Triadó-Margarit X., Castro F., et al. Individual fate and gut microbiome composition in the European wild rabbit (Oryctolagus cuniculus) // Scientific reports. 2021. No. 11 (1). Article number 766. DOI: 10.1038/s41598020-80782-4.

10. Ocasio-Vega C., Delgado R., Abad-Guamán R., et al. The effect of cellobiose on the health status of growing rabbits depends on the dietary level of soluble fiber // Journal of Animal Science. 2018. No. 96 (5). Pp. 1806-1817. DOI: $10.1093 /$ jas/sky106.

11. Доценко А. С., Гусаков А. В., Рожкова А. М., Волков П. В., Короткова О. Г., Синицын А. П. Ферментативный гидролиз целлюлозы смесями мутантных форм целлюлаз Penicillium verruculosum // Вестник Московского университета. Серия 2. Химия. 2018. Т. 59. № 2. С. 138-143.

12. Krasteva P. V., Bernal-Bayard J., Travier L., et al. Insights into the structure and assembly of a bacterial cellulose secretion system // Nature Communications. 2017. No. 8 (1). Article number 2065. DOI: 10.1038/s41467-017-01523-2.

13. Li D.-W. Biology of Microfungi. Springer, Cham, 2016. 650 p. DOI: 10.1007/978-3-319-29137-6.

14. Zhivin O., Dassa B., Moraïs S., et al. Unique organization and unprecedented diversity of the Bacteroides (Pseudobacteroides) cellulosolvens cellulosome system // Biotechnology for Biofuels. 2017. No. 10. Article number 211. DOI: 10.1186/s13068-017-0898-6.

15. Duarte M., Viegas A., Alves V. D., et al. A dual cohesin-dockerin complex binding mode in Bacteroides cellulosolvens contributes to the size and complexity of its cellulosome // Journal of Biological Chemistry. 2021. No. 296. Article number 100552. DOI: 10.1016/j.jbc.2021.100552.

16. Milani C., Mangifesta M., Mancabelli L., et al. Unveiling bifidobacterial biogeography across the mammalian branch of the tree of life // The ISME Journal. 2017. No. 11 (12). Pp. 2834-2847. DOI: 10.1038/ismej.2017.138.

17. Олескин А. В., Ботвинко И. В., Цавкелова Е. А. Колониальная организация и межклеточная коммуникация у микроорганизмов // Микробиология. 2000. Т. 69. № 3. С. 309-327.

18. Шендеров Б. А. Нормальная микрофлора и некоторые вопросы микроэкологической токсикологии // Антибиотики и медицинская биотехнология. 1987. Т. 32. № 3 С. 38-41.

19. Биргер М. О. Справочник по микробиологическим и вирусологическим методам исследования. Москва: Медицина, 1982. 464 с.

20. Лабинская А. С. Частная медицинская микробиология с техникой микробиологических исследований. Москва: Медицина, 2004. 576 с.

21. Лабинская А. С., Костюкова Н. Н., Иванова С. М. Частная медицинская микробиология и этиологическая диагностика инфекций. Москва: БИНОМ, 2012. 1152 с.

22. Rodríguez Hernáez J., Cerón Cucchi M. E., Cravero S., et al. The first complete genomic structure of Butyrivibrio fibrisolvens and its chromid // Microbial Genomics. 2018. No. 4 (10).Article number e000216. DOI: 10.1099/ mgen.0.000216.

23. Hagen L. H., Brooke C. G., Shaw C. A., et al. Proteome specialization of anaerobic fungi during ruminal degradation of recalcitrant plant fiber // The ISME Journal. 2021. No. 15. Pp. 421-434. DOI: 10.1038/s41396-020-00769-x.

24. Artegoitia V. M., Foote A. P., Lewis R. M., Freetly H. C. Rumen Fluid Metabolomics Analysis Associated with Feed Efficiency on Crossbred Steers // Scientific reports. 2017. No. 7 (1). Article number 2864. DOI: 10.1038/ s41598-017-02856-0.

25. Семенова Т. Н., Коротков Д. Ю., Первушин В. В. Видовой состав симбиоценоза толстого кишечника // Образование и наука в России и за рубежом. 2019. № 15 (63). С. 20-29. 
Об авторах:

Глеб Юрьевич Косовский ${ }^{1}$, доктор биологических наук, профессор РАН, главный научный сотрудник, директop, ORCID 0000-0003-3808-3086, AuthorID 353097; +7 (495) 744-26-42, niipzk@mail.ru

Елена Сергеевна Колесник ${ }^{1}$, младший научный сотрудник, ORCID 0000-0002-2465-7184, AuthorID 1050062; +7952 558-44-67, elena.rainis.lis@yandex.ru

Дмитрий Владимирович Попов ${ }^{1}$, кандидат биологических наук, ведущий научный сотрудник, заведующий отделом биотехнологии, ORCID 0000-0001-7422-5470, AuthorID 811001; +7 967 146-90-29,popov.bio@gmail.com

${ }^{1}$ Научно-исследовательский институт пушного звероводства и кролиководства имени В. А. Афанасьева, Родники, Россия

\title{
Chronic fistula to rabbit cecum microbiome study
}

\author{
G. Yu. Kosovskiy ${ }^{1 凶}$, E. S. Kolesnik¹, D. V. Popov ${ }^{1}$
}

${ }^{1}$ Scientific Research Institute of Fur-Bearing Animal Breeding and Rabbit Breeding named after V. A. Afanas'ev, Rodniki, Russia

E-mail: niipzk@mail.ru

Abstract. The purpose of this work is to approve a device for studying the microbiome of the gastrointestinal tract of mammals. The study of the quantitative and qualitative composition of the digestive tract microbiota is one of the promising directions in metagenomics. Knowledge obtained about the organization of microbiocenosis genome, the determination of species composition and study of metabolic relationships between its representatives not only expand the understanding of its role in the process of evolution, speciation and breeding but also provide a scientifically substantiated basis for targeting changes in the microbiome to form a phenotype (optimization of feed bioconversion, increasing overall resistance, etc.). Scientific novelty. For the first time, the main characteristics of cellulolytic bacteria isolated from the chyme of the rabbit cecum were isolated, cultured and described through a chronic fistula. Methods. In order to carry out research aimed to study mammalian microbiome and its correction, the need arises to develop methods of obtaining microbiome samples from experimental animals. To obtain access to the chyme of the cecum in 7 rabbits for up to 3 months the chronic fistulas developed in Scientific Research Institute of Fur-Bearing Animal Breeding and Rabbit Breeding n. a. V. A. Afanas'ev were installed. No negative manifestations were observed in the animals after installation of the fistulas, no changes in appetite were detected, and complete healing of the skin wound was determined on the 9th day. Diagnostic laparotomies performed 3 months after fistula placement revealed no pathological processes in any of the studied animals. Results. Characteristics of cellulolytic bacteria of the rabbit cecum Butirivibrio fibrisolvens and Ruminococcus flavefaciens were studied. Data on their enzymatic effects on dietary components, fermentation products, digestion and formation of organic substances and chemical compounds are presented.

Keywords: rabbit, microbiome, cellulosomes, fistula, chyme, Butirivibrio fibrisolvens, Ruminococcus flavefaciens.

For citation: Kosovskiy G. Yu., Kolesnik E. S., Popov D. V. Khronicheskaya fistula dlya izucheniya mikrobioma slepoy kishki krolika [Chronic fistula to rabbit cecum microbiome study] // Agrarian Bulletin of the Urals. 2021. No. 10 (213). Pp. 40-47. DOI: 10.32417/1997-4868-2021-213-10-40-47. (In Russian.)

Date of paper submission: 06.07.2021, date of review: 20.07.2021, date of acceptance: 02.09.2021.

\section{References}

1. Cotozzolo E., Cremonesi P., Curone G., et al. Characterization of Bacterial Microbiota Composition along the Gastrointestinal Tract in Rabbits // Animals (Basel). 2020. No. 11 (1). Article number 31. DOI: 10.3390/ani11010031. 2. Arrazuria R., Pérez V., Molina E., Juste R. A., Khafipour E., Elguezabal N. Diet induced changes in the microbiota and cell composition of rabbit gut associated lymphoid tissue (GALT) // Scientific Reports. 2018. No. 8 (1). Article number 14103. DOI: 10.1038/s41598-018-32484-1.

3. Bushtyreva I. O., Bushtyrev V. A., Barinova V. V., et al. Mikrobiom zhenskoy reproduktivnoy sistemy: voprosov bol'she, chem otvetov [Microbiome of the female reproductive system: there are more questions than answers] // Glavnyy vrach Yuga Rossii. 2018. No. 3 (62). Pp. 49-52. (In Russian.)

4. Kolodny O., Callahan B. J., Douglas A. E. The role of the microbiome in host evolution // Philosophical Transactions of the Royal Society. B. Biological Sciences. 2020. No. 375 (1808). Article number 20190588. DOI: 10.1098/ rstb.2019.0588.

5. Douglas-Escobar M., Elliott E., Neu J. Effect of intestinal microbial ecology on the developing brain // JAMA Pediatr. 2013. No. 167 (4). Pp. 374-379. DOI: 10.1001/jamapediatrics.2013.497.

6. Bercik P., Denou E., Collins J., et al. The intestinal microbiota affect central levels of brain-derived neurotropic factor and behavior in mice // Gastroenterology. 2011. No. 141 (2). Pp. 599-609. DOI: 10.1053/j.gastro.2011.04.052. 46 


\section{Agrarian Bulletin of the Urals No. 10 (213), 2021}

7. Velasco-Galilea M., Piles M., Viñas M., et al. Rabbit Microbiota Changes Throughout the Intestinal Tract // Frontiers in microbiology. 2018. No. 9. Article number 2144. DOI: 10.3389/fmicb.2018.02144.

8. Yang G., Zhao F., Tian H., Li J., Guo D. Effects of the dietary digestible fiber-to-starch ratio on pellet quality, growth and cecal microbiota of Angora rabbits // Asian-Australasian Journal of Animal Sciences. 2020. No. 33 (4). Pp. 623-633. DOI: 10.5713/ajas.19.0221.

9. Funosas G., Triadó-Margarit X., Castro F., et al. Individual fate and gut microbiome composition in the European wild rabbit (Oryctolagus cuniculus) // Scientific reports. 2021. No. 11 (1). Article number 766. DOI: 10.1038/s41598-020-80782-4.

10. Ocasio-Vega C., Delgado R., Abad-Guamán R., et al. The effect of cellobiose on the health status of growing rabbits depends on the dietary level of soluble fiber // Journal of Animal Science. 2018. No. 96 (5). Pp. 1806-1817. DOI: $10.1093 /$ jas/sky106.

11. Dotsenko A. S., Gusakov A. V., Rozhkova A. M., Volkov P. V., Korotkova O. G., and Sinitsyn A. P. Fermentativnyy gidroliz tsellyulozy smesyami mutantnykh form tsellyulaz Penicillium verruculosum [Enzymatic hydrolysis of cellulose by mixtures of mutant forms of Penicillium verruculosum cellulases] // Vestnik Moskovskogo universiteta. Seriya 2. Khimiya. 2018. Vol. 59. No. 2. Pp. 138-143. (In Russian.)

12. Krasteva P. V., Bernal-Bayard J., Travier L., et al. Insights into the structure and assembly of a bacterial cellulose secretion system // Nature Communications. 2017. No. 8 (1). Article number 2065. DOI: 10.1038/s41467-017-01523-2.

13. Li D.-W. Biology of Microfungi. Springer, Cham, 2016. 650 p. DOI: 10.1007/978-3-319-29137-6.

14. Zhivin O., Dassa B., Moraïs S., et al. Unique organization and unprecedented diversity of the Bacteroides (Pseudobacteroides) cellulosolvens cellulosome system // Biotechnology for Biofuels. 2017. No. 10. Article number 211. DOI: 10.1186/s13068-017-0898-6.

15. Duarte M., Viegas A., Alves V. D., et al. A dual cohesin-dockerin complex binding mode in Bacteroides cellulosolvens contributes to the size and complexity of its cellulosome // Journal of Biological Chemistry. 2021. No. 296. Article number 100552. DOI: 10.1016/j.jbc.2021.100552.

16. Milani C., Mangifesta M., Mancabelli L., et al. Unveiling bifidobacterial biogeography across the mammalian branch of the tree of life // The ISME Journal. 2017. No. 11 (12). Pp. 2834-2847. DOI: 10.1038/ismej.2017.138.

17. Oleskin A. V., Botvinko I. V., Tsavkelova E. A. Kolonial'naya organizatsiya i mezhkletochnaya kommunikatsiya u mikroorganizmov [Colonial organization and intercellular communication in microorganisms.] // Mikrobiologiya. 2000 T. 69. No. 3 Pp. 309-327. (In Russian.)

18. Shenderov B. A. Normal'naya mikroflora i nekotoryye voprosy mikroekologicheskoy toksikologii [Normal microflora and some issues of microecological toxicology] // Antibiotiki i meditsinskaya biotekhnologiya. 1987. T. 32. No. 3. Pp. 38-41. (In Russian.)

19. Birger M. O. Spravochnik po mikrobiologicheskim i virusologicheskim metodam issledovaniya [Handbook of Microbiological and Virological Research Methods]. Moscow: Meditsina, 1982. 464 p. (In Russian.)

20. Labinskaya A. S. Chastnaya meditsinskaya mikrobiologiya s tekhnikoy mikrobiologicheskikh issledovaniy [Private medical microbiology with microbiological research techniques]. Moscow: Meditsina, 2004. 576 p. (In Russian.) 21. Labinskaya A. S., Kostyukova N. N., Ivanova S. M. Chastnaya meditsinskaya mikrobiologiya i etiologicheskaya diagnostika infektsiy [Private medical microbiology and etiological diagnosis of infections. Moscow: BINOM, 2012. 1152 p. (In Russian.)

22. Rodríguez Hernáez J., Cerón Cucchi M. E., Cravero S., et al. The first complete genomic structure of Butyrivibrio fibrisolvens and its chromid // Microbial Genomics. 2018. No. 4 (10).Article number e000216. DOI: 10.1099/ mgen.0.000216.

23. Hagen L. H., Brooke C. G., Shaw C. A., et al. Proteome specialization of anaerobic fungi during ruminal degradation of recalcitrant plant fiber // The ISME Journal. 2021. No. 15. Pp. 421-434. DOI: 10.1038/s41396-020-00769-x. 24. Artegoitia V. M., Foote A. P., Lewis R. M., Freetly H. C. Rumen Fluid Metabolomics Analysis Associated with Feed Efficiency on Crossbred Steers // Scientific reports. 2017. No. 7 (1). Article number 2864. DOI: 10.1038/ s41598-017-02856-0.

25. Semenova T. N., Korotkov D. Yu., Pervushin V. V. Vidovoy sostav simbiotsenoza tolstogo kishechnika [Species composition of the symbiocenosis of the large intestine] // Obrazovaniye i nauka v Rossii i za rubezhom. 2019. No. 15 (63). Pp. 20-29. (In Russian.)

\section{Authors' information:}

Gleb Yu. Kosovskiy ${ }^{1}$, doctor of biological sciences, professor of the Russian Academy of Sciences, chief researcher, director, ORCID 0000-0003-3808-3086, AuthorID 353097; +7 (495) 744-26-42, niipzk@mail.ru

Elena S. Kolesnik ${ }^{1}$, junior researcher, ORCID 0000-0002-2465-7184, AuthorID 1050062; + 7952 558-44-67, elena.rainis.lis@yandex.ru

Dmitriy V. Popov ${ }^{1}$, candidate of biological sciences, leading researcher, head of the department of biotechnology, ORCID 0000-0001-7422-5470, AuthorID 811001; +7967 146-90-29, popov.bio@gmail.com

${ }^{1}$ Scientific Research Institute of Fur-Bearing Animal Breeding and Rabbit Breeding named after V. A. Afanas'ev, Rodniki, Russia 